Gut, 1986, 27, 309-316

\title{
Effect of glucocorticoids on rectal transport in normal subjects and patients with ulcerative colitis
}

\author{
G I SANDLE, J P HAYSLETT, AND H J BINDER
}

From the University Department of Medicine, Royal Victoria Infirmary, Newcastle-upon-Tyne, and Department of Internal Medicine, Yale University School of Medicine, New Haven, Connecticut, USA

SUMMARY The acute effects of single pharmacological doses of glucocorticoid hormones on net electrolyte and water transport and electrical potential difference (pd) in the rectum was studied in control subjects and in patients with either active or inactive ulcerative colitis, using a dialysis technique. Compared with 17 control subjects, nine patients with active ulcerative colitis exhibited marked decreases in net sodium absorption and rectal pd, while these transport parameters were normal in six patients with inactive ulcerative colitis. Intravenous administration of hydrocortisone hemisuccinate $(100 \mathrm{mg})$ resulted five hours later in significant and quantitatively similar increases in net sodium and water absorption and pd in nine control subjects, seven patients with active ulcerative colitis, and six patients with inactive ulcerative colitis. Intravenous administration of methylprednisolone phosphate $(40 \mathrm{mg})$ to eight control subjects produced increases in net sodium and water absorption and pd five hours later, which did not differ significantly from those produced by hydrocortisone; methylprednisolone induced similar changes in two patients with active ulcerative colitis. These results indicate that single pharmacological doses of glucocorticoids stimulate acute increases in rectal sodium and water absorption in control subjects and in patients with acute ulcerative colitis. The ability of systemically administered glucocorticoids to reduce diarrhoea in ulcerative colitis may therefore be related to direct effects on distal colonic sodium and water transport, as well as to their better known anti-inflammatory action.

Previous studies in patients with ulcerative colitis have shown that mucosal inflammation results in marked impairment of colonic sodium and water absorption. ${ }^{1-3}$ Inability of the colonic mucosa to absorb normal amounts of fluid and electrolytes may therefore contribute to diarrhoea, which is the commonest symptom of the disease. The administration of moderate to high doses of glucocorticoids is an important therapeutic manouevre in the management of both acute ulcerative colitis and Crohn's colitis, ${ }^{4-6}$ and these drugs have been generally assumed to reduce diarrhoea solely by exerting an anti-inflammatory effect on the mucosa. Recent in vivo studies, however, indicate that pharmacological doses of glucocorticoids stimulate sodium and water absorption in mammalian colon, both acutely (within five hours) ${ }^{7}$ and over longer time periods (one to three days) $^{7-9}$. In vitro studies have shown

Address for correspondence: Dr G I Sandle, Department of Medicine, Clinical Sciences Building, Hope Hospital, Eccles Old Road, Salford M6 8HD.

Received for publication 17 June 1985 that the main effect of glucocorticoids is to stimulate electrogenic sodium transport. ${ }^{10} 11$ These experimental findings raise the possibility that the efficacy of systematically administered glucocorticoids in acute ulcerative colitis reflects specific effects on colonic sodium and water transport, as well as more general effects produced by suppression of mucosal inflammation. In the present study we have investigated this possibility using an in vivo dialysis technique, and found that single pharmacological doses of hydrocortisone and methylprednisolone stimulate rectal sodium and water absorption to the same extent in both normal subjects, and patients with active (acute) and inactive (healed) ulcerative colitis after five hours. These findings indicate that inflamed and non-inflamed colonic mucosae respond normally to glucocorticoids, and suggest that the glucocorticoid induced decrease in diarrhoea in ulcerative colitis reflects stimulation of sodium and water absorption in addition to suppression of the underlying inflammatory process. 


\section{Methods}

\section{SUBJECTS}

After obtaining their informed written consent, studies were carried out in control subjects (seven men, two women, age 18-64 years), patients with active (acute) ulcerative colitis (three men, four women, age $22-65$ years), and patients with inactive (healed) ulcerative colitis (three men, three women, age 30-62 years), who were studied before and five hours after a single intravenous dose of hydrocortisone hemisuccinate $(100 \mathrm{mg})$. Another group of control subjects (five men, three women, age 18-63 years) was studied before and five hours after a single intravenous $40 \mathrm{mg}$ dose of methylprednisolone phosphate. The short term effects of methylprednisolone were also determined in two women patients (age 25-28 years) with active ulcerative colitis. Patients with active ulcerative colitis, who complained of diarrhoea and rectal bleeding for at least one month, were studied either at the time of the initial presentation or during a relapse, and were not receiving oral steroids or steroid enemas. Sigmoidoscopy in these patients revealed that the rectal mucosa was haemorrhagic and friable and confirmatory histology was obtained by mucosal biopsy. Patients with inactive ulcerative colitis were studied when they had been in remission for at least three months (one to two stools daily without rectal bleeding); they were maintained on sulphasalazine but were not receiving oral steroids or steroid enemas, and had normal rectal mucosae at sigmoidoscopy.

The rates of net electrolyte and water transport and electrical potential difference in the rectum were measured using a dialysis technique (Fig. 1) approved by the Ethical Committees of the Royal Victoria Infirmary, Newcastle upon Tyne, and Yale University School of Medicine. Dialysis bags were constructed from 6-8 cm lengths of Visking tubing $(1.43 \mathrm{~cm}$ diameter, Medicell International, London). One end was sealed using silk thread and epoxy resin, and after turning the bag inside out, two polyethylene tubes were introduced into the bag before sealing the other end around the tubes in a similar manner. One tube (Portex, internal diameter $3 \mathrm{~mm}$ ) acted as an electrical bridge and contained 4\% agar in Ringer solution containing (in $\mathrm{mmol} / \mathrm{l}$ ); sodium 120 , chloride 120 , potassium 30 and bicarbonate 30. The other tube (Portex, internal diameter $1 \mathrm{~mm}$ ) enabled Ringer solution to be introduced into the bag in situ. With the subject in the left lateral position, the bag was placed in the rectum via a sigmoidoscope after ensuring the mucosa was free of faecal material, such that the lower end was $8 \mathrm{~cm}$ from the anus. A cannula filled

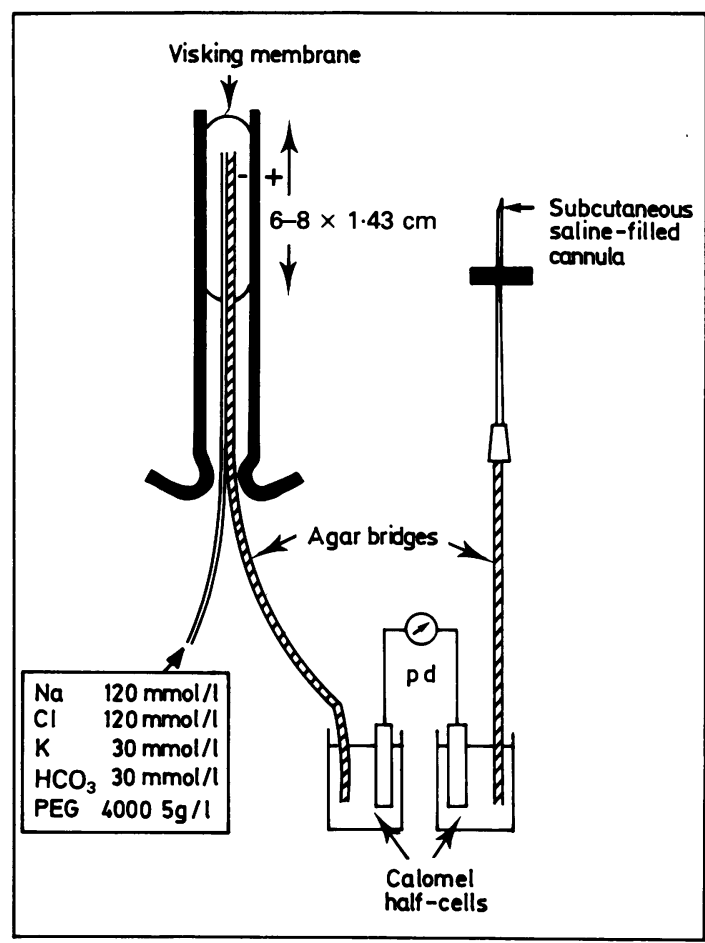

Fig. 1 Rectal dialysis technique. Bags constructed from Visking membrane were placed in the rectum at sigmoidoscopy. Potential difference ( $p d$ ) across the rectal mucosa (lumen negative with respect to plasma) was measured using intraluminal and subcutaneous agar-saline bridges connected to a portable voltmeter via calomel half-cells.

with $154 \mathrm{mmol} / \mathrm{l}$ sodium chloride was inserted subcutaneously on the lateral aspect of the thigh, and connected to a second agar bridge, after raising a small bleb beneath the skin. Both bridges were connected to a portable voltmeter (Avometer, Model DA 211) via balanced calomel half cells (Radiometer, Copenhagen, Model K401) in $3 \mathrm{~mol} / \mathrm{l}$ potassium chloride. Rectal potential difference measured in this way was normally lumen-negative.

Studies were done using Ringer solution (see above) containing polyethylene glycol 4000 (PEG; $5 \mathrm{~g} / \mathrm{l})$ as a non-absorbable marker. Preliminary studies showed that PEG concentration did not change when bags filled with this solution were immersed in PEG-free Ringer solution for two hours, indicating that there was no detectable loss of PEG through, or adsorption of PEG to, the dialysis membrane. Nine to twelve millilitres of Ringer solution were drawn into syringe $A$ which was weighed to an accuracy of $1 \mathrm{mg}$. An empty syringe B 
was weighed in a similar manner. The dialysis bag containing $0.25-0.5 \mathrm{ml}$ of PEG-free Ringer solution was placed in the rectum, and the PEG-containing Ringer solution in syringe $A$ added to the bag. The solution was withdrawn several times to ensure thorough mixing, and approximately $1.5 \mathrm{ml}$ was then removed from the bag at time zero using syringe $B$. Empty syringe $A$ and syringe $B$ containing the solution at time zero were weighed. The dialysis bag remained in the rectum for 60 minutes, during which time rectal pd was measured every 5-10 minutes to an accuracy of $0.1 \mathrm{mV}$. A mean value for pd was obtained for the dialysis period and corrected for the electrical asymmetry in the measuring system $(<1.5 \mathrm{mV})$. At the end of the dialysis period, the solution was removed from the bag for subsequent analysis. The bag was removed, cleaned, and the interior rinsed with $30 \mathrm{ml}$ PEG-free Ringer solution. Either hydrocortisone hemisuccinate $(100 \mathrm{mg})$ or methylpredinisolone phosphate $(40$ $\mathrm{mg}$ ) dissolved in $2 \mathrm{ml}$ normal saline was then administered as a single intravenous bolus, and rectal dialysis repeated after five hours using the samme bag.

Sodium, potassium, chloride, and bicarbonate were measured by auto-analyser (Beckman, Astra 8 ) and PEG was assayed turbidimetrically. ${ }^{12}$ The volume of solution in the dialysis bag at time zero $\left(\mathrm{V}_{0}\right.$ in $\mathrm{ml}$, assuming a specific gravity of 1$)$ was calculated as:

$$
V_{0}=\left[\left(A_{1}-A_{2}\right) \cdot \frac{5}{P^{2} G_{0}}\right]-\left(B_{1}-B_{2}\right)
$$

and the volume after the 60 minute dialysis period $\left(\mathrm{V}_{60}\right)$ was:

$$
\mathrm{V}_{60}=\mathrm{V}_{0} \cdot \frac{\mathrm{PEG}_{0}}{\mathrm{PEG}_{60}}
$$

where $A_{1}=$ weight (in grams) of syringe $A$ filled with Ringer solution, $A_{2}=$ weight of syringe $A$ empty, $B_{1}=$ weight of syringe $B$ containing Ringer solution at time zero, $B_{2}=$ weight of syringe $B$ empty, $\mathrm{PEG}_{0}=\mathrm{PEG}$ concentration $(\mathrm{g} / \mathrm{l})$ at time zero, and $\mathrm{PEG}_{60}=$ PEG concentration after the 60 minute dialysis period. The volume change in the bag during dialysis was calculated as $\left(\mathrm{V}_{0}-\mathrm{V}_{60}\right)$. Changes in content of individual electrolytes were calculated from $V_{0}, V_{60}$ and electrolyte concentrations at time zero and at the end of the dialysis period. The area of the bag (calculated from its length and radius) was assumed to equal the area of mucosa in contact with the solution,,$^{13}$ and net fluxes of water and electrolytes are therefore expressed as $\mu \mathrm{l} / \mathrm{cm}^{2} / \mathrm{h}$ and $\mu \mathrm{mol} / \mathrm{cm}^{2} / \mathrm{h}$, respectively. Positive values indicate loss from the bag - that is, net absorption and negative values indicate addition to the bag - that is net secretion.

Results are expressed as mean \pm SEM. Statistical comparisons were done using Student's $t$ test for paired or unpaired data, as appropriate.

\section{Results}

RECTAL ELECTROLYTE AND WATER TRANSPORT

AND POTENTIAL DIFFERENCE IN CONTROL

SUBJECTS AND PATIENTS WITH ULCERATIVE

COLITIS

Table 1 presents the mean rates of net electrolyte and water transport and pd in the control subjects, and the patients with active and inactive ulcerative colitis under basal (preglucocorticoid) conditions. In control subjects, there was a high lumen negative pd and net sodium absorption, but net water transport was not significantly different from zero. Despite the high intraluminal concentration of potassium (30 $\mathrm{mmol} / \mathrm{l})$, there was an appreciable net secretory flux of potassium $\left(-1.9 \pm 0.2 \mu \mathrm{mol} / \mathrm{cm}^{2} / \mathrm{h}\right)$. As shown in previous studies, ${ }^{14} 15$ net chloride absorption $\left(+4.8 \pm 0.7 \mu \mathrm{mol} / \mathrm{cm}^{2} / \mathrm{h}\right)$ was greater than net sodium absorption $\left(+2.5 \pm 0.6 \mu \mathrm{mol} / \mathrm{cm}^{2} / \mathrm{h}\right.$, $\mathrm{p}<0.02$ ), but equal in magnitude to net bicarbonate secretion $\left(-4 \cdot 2 \pm 0 \cdot 8 \mu \mathrm{mol} / \mathrm{cm}^{2} / \mathrm{h}\right)$.

Table 1 Basal rectal potential difference and electrolyte and water transport rates in control subjects, and patients with

\begin{tabular}{|c|c|c|c|c|c|c|}
\hline & $\begin{array}{l}\text { Potential } \\
\text { difference } \\
m V\end{array}$ & $\begin{array}{l}\text { Sodium } \\
\text { movement } \\
\mu \mathrm{mol} / \mathrm{cm}^{2} / \mathrm{h}\end{array}$ & $\begin{array}{l}\text { Potassium } \\
\text { movement } \\
\mu \mathrm{mol} / \mathrm{cm}^{2} / \mathrm{h}\end{array}$ & $\begin{array}{l}\text { Chloride } \\
\text { movement } \\
\mu \mathrm{mol} / \mathrm{cm}^{2} / \mathrm{h}\end{array}$ & $\begin{array}{l}\text { Bicarbonate } \\
\text { movement } \\
\mu \mathrm{mol} / \mathrm{cm}^{2} / \mathrm{h}\end{array}$ & $\begin{array}{l}\text { Water } \\
\text { movement } \\
\mu l / \mathrm{cm}^{2} / \mathrm{h}\end{array}$ \\
\hline $\begin{array}{l}\text { Controls }(n=17) \\
\text { Active ulcerative colitis }(n=9) \\
P^{*} \\
\text { Inactive ulcerative colitis }(n=6) \\
P^{*}\end{array}$ & $\begin{array}{l}-37 \pm 3 \\
-13 \pm 3 \\
<0 \cdot 001 \\
-39 \pm 2 \\
\text { NS }\end{array}$ & $\begin{array}{l}+2 \cdot 5 \pm 0 \cdot 6 \\
0 \cdot 0 \pm 0 \cdot 7 \\
<0 \cdot 025 \\
+4 \cdot 6 \pm 0 \cdot 8 \\
\text { NS }\end{array}$ & $\begin{array}{l}-1 \cdot 9 \pm 0 \cdot 2 \\
+0 \cdot 6 \pm 0 \cdot 4 \\
<0 \cdot 001 \\
-2 \cdot 4 \pm 0 \cdot 8 \\
\text { NS }\end{array}$ & $\begin{array}{l}+4 \cdot 8 \pm 0 \cdot 7 \\
+1 \cdot 1 \pm 0 \cdot 6 \\
<0 \cdot 005 \\
+4 \cdot 9 \pm 0 \cdot 8 \\
\text { NS }\end{array}$ & $\begin{array}{l}-4 \cdot 2 \pm 0 \cdot 8 \\
-0 \cdot 4 \pm 0 \cdot 5 \\
<0 \cdot 005 \\
-1 \cdot 9 \pm 0 \cdot 5 \\
<0 \cdot 05\end{array}$ & $\begin{array}{l}-1 \cdot 5 \pm 2 \cdot 4 \\
-8 \cdot 7 \pm 2 \cdot 5 \\
<0 \cdot 1 \\
-6 \cdot 3 \pm 3 \cdot 9 \\
\text { NS }\end{array}$ \\
\hline
\end{tabular}
active and inactive ulcerative colitis

Results are expressed as mean \pm SEM. Rectal potential difference was lumen-negative. For electrolyte and water transport, $+=$ net absorption and $-=$ net secretion. $\mathbf{n}=$ the number of subjects studied. ${ }^{*}=$ difference compared with control value. 
In contrast with the control subjects, patients with active ulcerative colitis exhibited marked differences in all aspects of rectal transport. Rectal pd in these patients varied between $-6.2 \mathrm{mV}$ and $-31.1 \mathrm{mV}$, the lowest values being associated with the most marked macroscopic changes of the rectal mucosa. The $65 \%$ decrease in rectal pd in this group of patients was associated with complete loss of net sodium absorption and net potassium secretion, and a tendency to increased net water secretion, although this change was not statistically significant $(\mathrm{p}<0 \cdot 1)$. Compared with control subjects, mucosal inflammation in these patients also resulted in significant decreases in net chloride absorption (by $77 \%, \mathrm{p}<0.005)$ and net bicarbonate secretion (by $79 \%, \mathrm{p}<0.005)$.

In patients with inactive ulcerative colitis, rectal pd and the rates of net sodium, potassium, chloride and water transport were not significantly different from control values, although bicarbonate secretion remained impaired (by $55 \%, \mathrm{p}<0.05$ ).

\section{EFFECT OF HYDROCORTISONE ON RECTAL} TRANSPORT IN CONTROL SUBJECTS AND PATIENTS WITH ULCERATIVE COLITIS

After the basal dialysis period, $100 \mathrm{mg}$ hydrocortisone hemisuccinate was administered as a single intravenous bolus to control subjects and patients with active ulcerative colitis, and the rectal dialysis repeated five hours later. Patients with inactive ulcerative colitis were studied in a similar manner to determine whether healed rectal mucosa responded normally to the glucocorticoid.

Table 2 shows that in the control subjects, hydrocortisone administration increased rectal pd by $17 \mathrm{mV}(\mathrm{p}<0.025)$, net sodium and water absorption by $2.3 \mu \mathrm{mol} / \mathrm{cm}^{2} / \mathrm{h}(\mathrm{p}<0.005)$ and $12.5 \mu \mathrm{l} / \mathrm{cm}^{2} / \mathrm{h}$ $(p<0.02)$ respectively, and net potassium secretion by $1.2 \mu \mathrm{mol} / \mathrm{cm}^{2} / \mathrm{h}(\mathrm{p}<0.05)$. Despite the marked - abnormalities in basal transport in patients with active ulcerative colitis, hydrocortisone produced changes which were similar to those in control subjects. In patients with inactive ulcerative colitis, basal transport parameters were similar to those in control subjects, and responded normally to hydrocortisone. In contrast with the hydrocortisone induced changes in sodium, water, and potassium transport in the three groups, the glucocorticoid had no effect on net chloride absorption or net bicarbonate secretion.

\section{EFFECT OF METHYLPREDNISOLONE ON RECTAL}

TRANSPORT IN CONTROL SUBJECTS AND PATIENTS WITH ACTIVE ULCERATIVE COLITIS

The data presented in Table 3 show the effects of a single $40 \mathrm{mg}$ dose of methylprednisolone on rectal transport in control subjects and two patients with active ulcerative colitis. Preliminary studies in three control subjects (results not shown) indicated that a single $16 \mathrm{mg}$ dose of the glucocorticoid had no effect on rectal pd or net sodium absorption. Forty milligrams of methylprednisolone resulted in significant increases in rectal pd and net sodium absorption and net potassium secretion in the control subjects. Net water absorption increased in six of the eight subjects, but the change for the group was not statistically significant. Methylprednisolone also stimulated a small increase in net chloride absorption $\left(+4.7 \pm 1.2 v s+6.4 \pm 1.1 \mu \mathrm{mol} / \mathrm{cm}^{2} / \mathrm{h}, \mathrm{p}<0.05\right)$, but there was no change in net bicarbonate secretion

Table 2 Effect of hydrocortisone hemisuccinate $(H C)$ on rectal transport in control subjects, and patients with active and inactive ulcerative colitis

\begin{tabular}{|c|c|c|c|c|c|c|}
\hline & $\begin{array}{l}\text { Potential } \\
\text { difference } \\
m V\end{array}$ & $\begin{array}{l}\text { Sodium } \\
\text { movement } \\
\mu \mathrm{mol} / \mathrm{cm}^{2} / \mathrm{h}\end{array}$ & $\begin{array}{l}\text { Potassium } \\
\text { movement } \\
\mu \mathrm{mol} / \mathrm{cm}^{2} / \mathrm{h}\end{array}$ & $\begin{array}{l}\text { Chloride } \\
\text { movement } \\
\mu \mathrm{mol} / \mathrm{cm}^{2} / \mathrm{h}\end{array}$ & $\begin{array}{l}\text { Bicarbonate } \\
\text { movement } \\
\mu \mathrm{mol} / \mathrm{cm}^{2} / \mathrm{h}\end{array}$ & $\begin{array}{l}\text { Water } \\
\text { movement } \\
\mu l / \mathrm{cm}^{2} / \mathrm{h}\end{array}$ \\
\hline \multicolumn{7}{|c|}{ Controls $(n=9)$} \\
\hline Pre-HC & $-37 \pm 5$ & $+3 \cdot 1 \pm 0 \cdot 6$ & $-2 \cdot 0 \pm 0 \cdot 3$ & $+4 \cdot 8 \pm 0 \cdot 8$ & $-3 \cdot 6 \pm 0 \cdot 5$ & $-3 \cdot 7 \pm 3 \cdot 0$ \\
\hline Post-HC & $-54 \pm 8$ & $+5.4 \pm 0.7$ & $-3 \cdot 2 \pm 0 \cdot 6$ & $+5 \cdot 9 \pm 0.4$ & $-3 \cdot 3 \pm 0 \cdot 4$ & $+8 \cdot 8 \pm 3 \cdot 0$ \\
\hline $\mathbf{P}^{*}$ & $<0.025$ & $<0.005$ & $<0.05$ & NS & NS & $<0.02$ \\
\hline \multicolumn{7}{|c|}{ Active ulcerative colitis $(n=7)$} \\
\hline Pre-HC & $-11 \pm 3$ & $+0 \cdot 1 \pm 0.5$ & $+0.5 \pm 0.3$ & $+1 \cdot 5 \pm 0.5$ & $-0.6 \pm 0.5$ & $-7 \cdot 6 \pm 3 \cdot 1$ \\
\hline Post-HC & $-27 \pm 7$ & $+2 \cdot 6 \pm 0 \cdot 8$ & $-0 \cdot 5 \pm 0.5$ & $+2 \cdot 8 \pm 0.7$ & $-0 \cdot 3 \pm 0 \cdot 2$ & $+3 \cdot 3 \pm 2 \cdot 2$ \\
\hline $\mathbf{P}^{*}$ & $<0 \cdot 025$ & $<0.02$ & $<0.02$ & NS & NS & $<0.025$ \\
\hline \multicolumn{7}{|c|}{ Inactive ulcerative colitis $(n=6)$} \\
\hline Pre-HC & $-39 \pm 2$ & $+4 \cdot 6 \pm 0 \cdot 8$ & $-2 \cdot 4 \pm 0.8$ & $+4 \cdot 9 \pm 0 \cdot 8$ & $-1 \cdot 9 \pm 0 \cdot 5$ & $-6 \cdot 3 \pm 3 \cdot 9$ \\
\hline Post-HC & $-55 \pm 4$ & $+6 \cdot 7 \pm 1 \cdot 3$ & $-3 \cdot 2 \pm 0.9$ & $+6 \cdot 1 \pm 1 \cdot 1$ & $-1 \cdot 7 \pm 0 \cdot 3$ & $+4 \cdot 6 \pm 4 \cdot 8$ \\
\hline$P^{*}$ & $<0.005$ & $<0.025$ & $<0.02$ & NS & NS & $<0.025$ \\
\hline
\end{tabular}

Results are expressed as mean \pm SEM. Each subject was studied before and five hours after a single intravenous dose of hydrocortisone hemisuccinate $(\mathrm{HC} ; 100 \mathrm{mg})$. Rectal potential difference was lumen-negative. For electrolyte and water transport, $+=$ net absorption and $-=$ net secretion. $\mathrm{n}=$ the number of subjects studied. ${ }^{*}=$ difference between pre- and post-HC values. 
Table 3 Effect of methylprednisolone phosphate (MP) on rectal transport in control subjects and patients with active ulcerative colitis

\begin{tabular}{|c|c|c|c|c|}
\hline & $\begin{array}{l}\text { Potential } \\
\text { difference } \\
m V\end{array}$ & $\begin{array}{l}\text { Sodium } \\
\text { movement } \\
\mu \mathrm{mol} / \mathrm{cm}^{2} / \mathrm{h}\end{array}$ & $\begin{array}{l}\text { Potassium } \\
\text { movement } \\
\mu \mathrm{mol} / \mathrm{cm}^{2} / \mathrm{h}\end{array}$ & $\begin{array}{l}\text { Water } \\
\text { movement } \\
\mu l / \mathrm{cm}^{2} / \mathrm{h}\end{array}$ \\
\hline \multicolumn{5}{|c|}{ Controls $(n=8)$} \\
\hline $\begin{array}{l}\text { Pre-MP } \\
\text { Post-MP } \\
\text { P* }^{*}\end{array}$ & $\begin{array}{l}-38 \pm 5 \\
-47 \pm 3 \\
<0.05\end{array}$ & $\begin{array}{l}+1.9 \pm 1.0 \\
+5.5 \pm 0.7 \\
<0.005\end{array}$ & $\begin{array}{l}-1 \cdot 8 \pm 0.2 \\
-3.0 \pm 0.6 \\
<0.05\end{array}$ & $\begin{array}{l}+1 \cdot 0 \pm 3 \cdot 8 \\
+7 \cdot 8 \pm 5 \cdot 6 \\
\text { NS }\end{array}$ \\
\hline \multicolumn{5}{|c|}{ Active ulcerative colitis } \\
\hline $\begin{array}{l}\text { Pre-MP } \\
\text { Post-MP }\end{array}$ & $\begin{array}{l}-9 \\
-24\end{array}$ & $\begin{array}{l}-4 \cdot 3 \\
+4 \cdot 0\end{array}$ & $\begin{array}{l}+3 \cdot 1 \\
-0.4\end{array}$ & $\begin{array}{l}-14 \cdot 7 \\
+1 \cdot 4\end{array}$ \\
\hline $\begin{array}{c}\text { Patient 2: } \\
\text { Pre-MP } \\
\text { Post-MP }\end{array}$ & $\begin{array}{l}-31 \\
-61\end{array}$ & $\begin{array}{l}+3.4 \\
+8.8\end{array}$ & $\begin{array}{l}-0.8 \\
-2 \cdot 3\end{array}$ & $\begin{array}{l}-10 \cdot 6 \\
-1 \cdot 5\end{array}$ \\
\hline
\end{tabular}

Results in control subjects are expressed as mean $\pm S E M$, and individual results are shown from the two patients with active ulcerative colitis. Each subject was studied before and five hours after a single intravenous dose of methylprednisolone phosphate (MP; $40 \mathrm{mg}$ ). Rectal potential difference was lumen-negative. For electrolyte and water transport, $+=$ net absorption and $-=$ net secretion. $\mathrm{n}=$ the number of subjects studied. ${ }^{*}=$ difference between pre- and post-MP values. $\left(-4.9 \pm 1.6\right.$ vs $\left.-4.4 \pm 1.0 \mu \mathrm{mol} / \mathrm{cm}^{2} / \mathrm{h}\right)$. Similar changes in rectal pd and sodium, potassium, and water transport occurred in the two patients with active ulcerative colitis, indicating that inflamed rectal mucosa responded normally to $40 \mathrm{mg}$ of methylprednisolone.

Figure 2 compares the magnitude of the changes produced by a single $100 \mathrm{mg}$ dose of hydrocortisone and by a single $40 \mathrm{mg}$ dose of methylprednisolone. It should be noted that hydrocortisone produced almost identical increases in rectal pd and net sodium and water absorption in the control subjects, and in the patients with active and inactive ulcerative colitis. Furthermore, in control subjects, the increases in rectal pd and net sodium and water absorption produced by methylprednisolone $(9 \pm 3$ $\mathrm{mV} ; 3.7 \pm 0.9 \mu \mathrm{mol} / \mathrm{cm}^{2} / \mathrm{h}$; and $7.8 \pm 6.0 \mu \mathrm{l} / \mathrm{cm}^{2} / \mathrm{h}$, respectively) were not significantly different from those produced by hydrocortisone $(17 \pm 6 \mathrm{mV}$, $\mathrm{p}>0.2 ; 2.4 \pm 0.6 \mu \mathrm{mol} / \mathrm{cm}^{2} / \mathrm{h}, \mathrm{p}>0.2 ;$ and $12.5 \pm 3.8$ $\mu \mathrm{l} / \mathrm{cm}^{2} / \mathrm{h}, \mathrm{p}>0 \cdot 5$, respectively).

\section{Discussion}

Rectal dialysis is now established as a convenient and sensitive method for obtaining simultaneous measurements of transmucosal pd and net move-

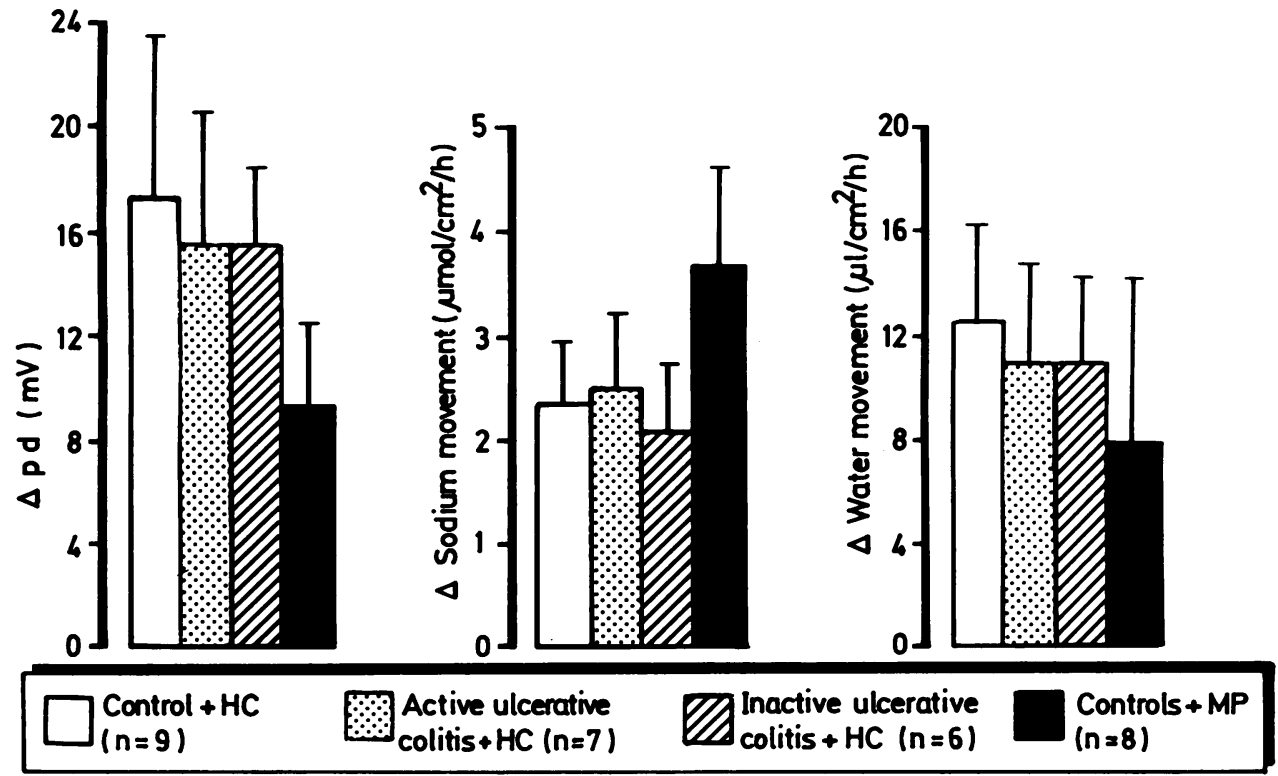

Fig. 2 Changes in potential difference $(p d)$ and net sodium and water movement observed in control subjects and patients with ulcerative colitis five hours after the administration of hydrocortisone hemisuccinate (HC; $100 \mathrm{mg})$ or methylprednisolone phosphate (MP; $40 \mathrm{mg})$. There were no significant differences in the increases in pd and sodium and water absorption between the four groups. 
ments of electrolyte and water in normal subjects and patients with inflammatory bowel disease. ${ }^{313}$ More than $90 \%$ of electrolyte and water transport takes place across the mucosa in contact with the dialysis bag, the dialysis membrane itself providing no diffusional barrier, and net fluxes may therefore be expressed per unit area of mucosa. ${ }^{13}$ Previous studies in normal human rectum have consistently shown greater rates of net water, sodium and chloride absorption than in the present experiments, ${ }^{2} 313$ but these differences may be explained by the modifications we made to the technique described originally by Edmonds. ${ }^{13}$ Firstly, he used narrow dialysis bags $(0.5 \mathrm{~cm}$ diameter $)$, whereas we used wider bags $(1.43 \mathrm{~cm}$ diameter) which were closer to the width of the rectum. Compared with a narrow bag, a wide bag of similar length provides a three-fold increase in the volume to surface area ratio, which may lead to underestimation of the relatively small net fluxes of water and electrolytes that occur in the rectum. Our finding of zero net water movement in the rectum, however, agrees with the results of rectal perfusion studies. ${ }^{16}$ Secondly, we used PEG 4000 as a volume marker, rather than directly determine the change in weight of the bag during the dialysis period. ${ }^{13}$ This modification has been useful in other studies, ${ }^{17}$ as the bag may be washed out in situ and further dialyses carried out in the same subject with solutions of different ionic composition. Thirdly, the higher rates of net sodium and chloride absorption (and hence water absorption) observed in previous studies may be related to higher initial concentrations of these ions in the rectal lumen $(145-150 \mathrm{mmol} / \mathrm{l} v \mathrm{~s}$ $120 \mathrm{mmol} / 1$ in the present study). ${ }^{213}$

\section{EFFECT OF ULCERATIVE COLITIS ON RECTAL}

\section{TRANSPORT}

In control subjects, the basal values of rectal pd and electrolyte transport rates were similar to those reported by other investigators. ${ }^{23} 13$ Sodium absorption in the human descending colon and rectum is an electrogenic process which is largely responsible for the high lumen-negative $\mathrm{pd}^{1819}$ Chloride absorption is mediated by a combination of passive transport along favourable electrochemical gradients, and an electroneutral chloridebicarbonate exchange process. ${ }^{1820} 21$ Potassium secretion reflects (i) passive movement of potassium from plasma to lumen, which is driven by the lumen-negative $\mathrm{pd}^{320}$ and (ii) an active (pdindependent) potassium secretory process. ${ }^{18}$

In the present, as in previous studies, mucosal inflammation in the patients with active ulcerative colitis resulted in marked decreases in rectal pd, net sodium absorption, and net chloride absorp- tion. ${ }^{1-32223}$ Loss of rectal pd is generally held to reflect the decrease in net sodium absorption, ${ }^{1}{ }^{3} 23$ but the link between these changes remains unclear. It has been suggested that the sodium transport process per se is normal in active ulcerative colitis, but transported sodium moves back into the lumen via 'leak' pathways in the inflamed mucosa, leading to decreases in net sodium absorption and rectal pd. ${ }^{2}$ Alternatively, the sodium transport process may be abnormal, as suggested by in vitro studies in which mucosal inflammation was associated with a diminution of the unidirectional sodium flux from mucosa to serosa resulting in a decrease in net sodium absorption. ${ }^{23}$ In any event, loss of the transmucosal pd in active ulcerative colitis explains, at least in part, the $69 \%$ reduction in net chloride absorption, ${ }^{2}$ although the inflammatory process may also impair chloride-bicarbonate exchange, as net bicarbonate secretion fell by $79 \%$. It should also be noted that in contrast with previous in vivo studies, where concentrations of potassium in the dialysis solution and plasma were similar, ${ }^{3}$ a decrease rather than an increase in net potassium secretion was observed in patients with active ulcerative colitis. This difference probably reflects (i) the high intraluminal potassium concentration used in the present study $(30 \mathrm{mmol} / \mathrm{l})$, together with (ii) loss of the pd-dependent (passive) component of potassium secretion.

The patients with inactive ulcerative colitis were receiving only sulphasalazine when studied, and the normal rectal mucosal appearances and pds were associated with full restoration of sodium, potassium and chloride transport, while water transport did not differ significantly from normal. An incidental but unexplained finding was the persistence of impaired bicarbonate secretion. Thus, despite the marked abnormalities that occur during acute mucosal inflammation, the most important facets of distal colonic electrolyte transport return to normal during remission.

EFFECTS OF GLUCOCORTICOIDS ON RECTAL TRANSPORT IN CONTROL SUBJECTS AND PATIENTS WITH ULCERATIVE COLITIS

The present study shows for the first time that pharmacological doses of glucocorticoid hormones stimulate acute changes in electrolyte and water transport across normal and inflamed human rectal mucosa. The increases in pd and sodium and water absorption induced by hydrocortisone and methylprednisolone in normal human rectum are qualitatively similar to the changes observed in rat colon five hours after the administration of a single pharmacological dose $(600 \mu \mathrm{g} / 100 \mathrm{~g}$ body weight $)$ of the glucocorticoid dexamethasone. ${ }^{7}$ Dexametha- 
sone stimulates an early rise in electrogenic sodium transport, ${ }^{11}$ which occurs in the time frame required for the drug to bind to glucocorticoid receptors in the mucosa, and hydrocortisone and methylprednisolone probably exert a similar effect in the human rectum. It should be emphasised that these changes in rectal transport are very similar to those produced in descending colon and rectum by aldosterone ${ }^{102425}$ but it is unclear whether high doses of hydrocortisone and methylprednisolone act after binding to glucocorticoid receptors, to mineralocorticoid receptors or both, as both types of receptor are present in mammalian colon. ${ }^{26}$ Although physiological doses of dexamethasone restore colonic pd and sodium absorption in adrenalectomised animals to control values (suggesting an effect via glucocorticoid receptors), ${ }^{27}$ equivalent studies have not been done in man. The increases in net potassium secretion produced by hydrocortisone and methylprednisolone in the present study have also been observed in rat colon five hours after dexamethasone treatment, ${ }^{9}$ and these acute changes may reflect an increase in the pd-dependent (passive) secretion of potassium.

The results obtained with hydrocortisone and methylprednisolone in patients with active ulcerative colitis indicate that the sodium transport process is able to respond normally to glucocorticoids in the presence of mucosal inflammation. The fact that hydrocortisone increases rectal pd and net sodium absorption to the same extent in control subjects, patients with active ulcerative colitis and patients with inactive ulcerative colitis (Fig. 2) indicates that the glucocorticoid is probably exerting a similar effect on the rectal mucosa in all three groups - that is, stimulation of electrogenic sodium transport.

It should be noted that mucosal concentrations of prostanoids increase in active ulcerative colitis ${ }^{28} 29$ and these secretagogues may contribute to the abnormalities of rectal electrolyte transport seen in this disease. ${ }^{30}{ }^{31}$ Studies in patients with ulcerative colitis have shown that short term (12-72 hours) treatment with oral prednisolone ${ }^{32}$ or long term (up to four weeks) with prednisolone enemas ${ }^{33}$ significantly decreases release of prostanoids into the lumen, apparently by inhibiting phospholipases involved in prostanoid synthesis. ${ }^{34}$ We cannot completely exclude the possibility that our results reflect inhibition of prostanoid release by glucocorticoids (at least in inflamed mucosa), ${ }^{35}{ }^{36}$ but it is interesting that dexamethasone has no effect on basal prostanoid production - that is, in the absence of inflammation. ${ }^{37}$ In addition, flurbiprofen, an inhibitor of prostanoid synthesis, has no beneficial effect on rectal pd and sodium absorption in patients with active ulcerative colitis, even though prostanoid release from the mucosa decreases. ${ }^{38}$ It therefore seems likely that the similar responses to glucocorticoids seen in the control subjects and the patients with ulcerative colitis in the present study reflect direct effects on sodium and water transport, rather than secondary effects associated with a reduction in mucosal prostanoid levels.

In conclusion, the present study shows that single pharmacological doses of glucocorticoids produce acute and significant increases in net sodium and water absorption across normal, inflamed and healed rectal mucosa. Human rectum and descending colon share the same sodium transport process, and glucocorticoids probably stimulate sodium and water absorption along the entire left side of the colon. It therefore seems likely that glucocorticoids reduce diarrhoea in active ulcerative colitis by exerting direct effects on colonic sodium and water transport, as well as by the usually accepted explanation that they suppress mucosal inflammation.

This study was supported in part by USPHS research grants (AM 18777 and AM 18061) from the National Institute of Arthritis, Diabetes, and Digestive and Kidney Diseases and the General Clinical Research Center (RR-125) from the Division of Research Resources. Dr Sandle was the recipient of Senior Research Fellowships from the National Foundation for Ileitis and Colitis (Yale) and the Medical Research Council (Newcastle).

\section{References}

1 Rask-Madsen J. Simultaneous measurement of electrical polarization and electrolyte transport by the entire normal and inflamed human colon during in vivo perfusion. Scand J Gastroenterol 1973; 8: 327-36.

2 Rask-Madsen J, Jensen PB. Electrolyte transport capacity and electrical potentials of the normal and the inflamed human rectum in vivo. Scand J Gastroenterol 1973; 8: 169-75.

3 Edmonds CJ, Pilcher D. Electrical potential difference and sodium and potassium fluxes across rectal mucosa in ulcerative colitis. Gut 1973; 14: 784-9.

4 Truelove SC, Witts LJ. Cortisone and corticotrophin in ulcerative colitis. Br Med J 1959; 1: 387-94.

5 Summers RW, Switz DM, Sessions JT et al. National Cooperative Crohn's Disease Study: results of drug treatment. Gastroenterology 1979; 77: 847-69.

6 Malchow H, Ewe K, Brandes JW et al. European Cooperative Crohn's Disease Study (ECCDS): results of drug treatment. Gastroenterology 1984; 86: 249-66.

7 Binder HJ. Effect of dexamethasone on electrolyte 
transport in the large intestine of the rat. Gastroenterology 1978; 75: 212-7.

8 Charney AN, Kinsey MD, Myers L, Giannella RA, Gots RE. $\mathrm{Na}^{+}-\mathrm{K}^{+}$activated adenosine triphosphatase and intestinal electrolyte transport. Effects of adrenal steroids. J Clin Invest 1975; 56: 653-60.

9 Charney AN, Wallach J, Ceccarelli S, Donowitz M, Costenbader CL. Effects of spironolactone and amiloride on corticosteroid-induced changes in colonic function. Am J Physiol 1981; 241: G300-5.

10 Foster ES, Zimmerman TW, Hayslett JP, Binder HJ. Corticosteroid alteration of active electrolyte transport in rat distal colon. Am J Physiol 1983; 245: G668-75.

11 Sandle GI, Lewis SA, Hayslett JP, Binder HJ. Dexamethasone induces amiloride-sensitive $\mathrm{Na}$ transport in rat distal colon. [Abstract] Clin Sci 1982; 62: 30P.

12 Hyden SA. Turbidimetric method for the determination of high polyethylene glycol in biological materials. Ann R Agric Coll Sweden 1955; 22: 139-45.

13 Edmonds CJ. Absorption of sodium and water by human rectum measured by a dialysis method. Gut 1971; 12: 356-62.

14 Devroede GJ, Phillips SF. Studies of the perfusion technique for colonic absorption. Gastroenterology 1969; 56: 92-100.

15 Bown RL, Sladen GE, Rousseau B, Gibson JA, Clark ML, Dawson AM. A study of water and electrolyte transport by excluded human colon. Clin Sci 1972; 43: 891-902.

16 Devroede GJ, Phillips SF. Failure of the human rectum to absorb electrolytes and water. Gut $1970 ; 11$ : 438-42.

17 Sandle GI, Gaiger E. Increased rectal $\mathrm{K}$ secretion in patients with chronic renal failure. [Abstract] Clin Sci 1985; 68: 39P.

18 Hawker PC, Mashiter K, Turnberg LA. Mechanisms of transport of $\mathrm{Na}, \mathrm{Cl}$ and $\mathrm{K}$ in the human colon. Gastroenterology 1978; 74: 1241-7.

19 Wills NK, Alles WP, Sandle GI, Binder HJ. Apical membrane properties and amiloride binding kinetics of the human descending colon. Am J Physiol 1984; 247: G749-57.

20 Devroede GJ, Phillips SF. Conservation of sodium, chloride and water by the human colon. Gastroenterology 1969; 56: 101-9.

21 Levitan R, Fordtran JS, Burrows BA, Ingelfinger FJ. Water and salt absorption in the human colon. $J$ Clin Invest 1962; 41: 1754-9.

22 Archampong EQ, Harris J, Clark CG. The absorption and secretion of water and electrolytes across the healthy and the diseased human colonic mucosa measured in vitro. Gut 1972; 13: 880-6.

23 Hawker PC, McKay JS, Turnberg LA. Electrolyte transport across colonic mucosa from patients with inflammatory bowel disease. Gastroenterology 1980; 79: 508-11.

24 Edmonds CJ, Richards P. Measurement of rectal potential difference as an instant screening test for hyperaldosteronism. Lancet 1970; 2: 624-7.

25 Frizzell RA, Schultz SG. Effect of aldosterone on ion transport by rabbit colon in vitro. J. Membr Biol 1978; 39: 1-26.

26 Pressley L, Funder JW. Glucocorticoid and mineralocorticoid receptors in gut mucosa. Endocrinology 1975; 97: 588-96.

27 Bastl CP, Binder HJ, Hayslett JP. Role of glucocorticoids and aldosterone in maintenance of colonic cation transport. Am J Physiol 1980; 238: F181-6.

28 Sharon P, Ligumsky M, Rachmilewitz D, Zor U. Role of prostaglandins in ulcerative colitis. Enhanced production during active disease and inhibition by sulphasalazine. Gastroenterology 1978; 75: 638-49.

29 Gould SR, Brash AR, Conolly ME. Increased prostaglandin production in ulcerative colitis. Lancet 1977; 2: 98.

30 Kimberg DV. The ubiquitous prostaglandins and their role in ulcerative colitis. Gastroenterology 1978; 75: 748-50.

31 Rampton DS, Sladen GE, Youlten LJF. Rectal mucosal prostaglandin $\mathrm{E}_{2}$ release and its relation to disease activity, electrical potential difference, and treatment in ulcerative colitis. Gut 1980; 21 : 591-6.

32 Lauritsen K, Laursen LS, Bukhave K, Rask-Madsen J. Effects of systemic prednisolone on arachidonic acid metabolites determined by equilibrium in vivo dialysis of rectum in severe relapsing ulcerative colitis. [Abstract] Gastroenterology 1985; 88: 1466.

33 Lauritsen K, Laursen LS, Bukhave K, Rask-Madsen J. Effect of topical 5-aminosalicylic acid (5-ASA) and prednisolone on prostaglandin (PG) $\mathrm{E}_{2}$ and leukotriene $(\mathrm{LT}) \mathrm{B}_{4}$ levels determined by equilibrium in vivo dialysis of rectum in relapsing ulcerative colitis (UC). [Abstract] Gastroenterology 1985; 88: 1466.

34 Flower RJ, Blackwell GJ. Anti-inflammatory steroids induce biosynthesis of a phospholipase $\mathbf{A}_{2}$ inhibitor which prevents prostaglandin generation. Nature (Lond) 1979; 278: 456-9.

35 Hawkey CJ, Truelove SC. Effect of prednisolone on prostaglandin synthesis by rectal mucosa in ulcerative colitis: investigation by laminar flow bioassay and radioimmunoassay. Gut 1981; 22: 190-3.

36 Ligumsky M, Karmeli F, Sharon P. Zor U, Cohen F, Rachmilewitz D. Enhanced thromboxane $A_{2}$ and prostacyclin production by cultured rectal mucosa in ulcerative colitis and its inhibition by steroids and sulphasalazine. Gastroenterology 1981; 81: 444-9.

37 Náray-Fejes-Tóth, A, Fejes-Tóth G, Fischer C, Frölich JC. Effect of dexamethasone on in vivo prostanoid production in the rabbit. J Clin Invest 1984; 74: 120-3.

38 Rampton DS, Sladen GE. The relationship between rectal mucosal prostaglandin production and water and electrolyte transport in ulcerative colitis. Digestion 1984; 30: 13-22. 